\title{
MCLUSION RATE AND PHYSIOLOGICAL EFFECTS OF PROLONGED FEEDING OF COCOA BEAN CAKE ON LAYERS
}

\author{
A.A. ODUNSI \\ Depayment of Animal Production and Health, Ladoke Akintola University of Technology, \\ Ogbomoso, Nigeria.
}

Recelved 04 October, 1994; Accepted 19 November, 1996.

\begin{abstract}
The effect of inclusion of cocoa bean cake (CBC) on productive performance and physiological response of Isa Brown pullets to prolonged feeding of CBC were investigated. Dietary inclusions of CBC (0, 50, 100 and $200 \mathrm{~g} \mathrm{~kg}^{-1}$ diet) were monitored in typical poultry diets from day old to 51 weeks of age. Sexual maturity and attainment of $50 \%$ Hen-day production were delayed with increasing level of CBC. Egg quality indices were higher $(\mathrm{P}<0.05)$ at $200 \mathrm{~g} \mathrm{Kg} \mathbf{g}^{-1} \mathrm{CBC}$ diet but with reduced $(P<0.05)$ shell thickness. CBC had no significant influence on yolk or whole egg cholesterol, follicular weight and number. Layers on 0 and $50 \mathrm{~g} \mathrm{Kg}^{-1} \mathrm{CBC}$ diets had higher $(P<0.05)$ percentage of yellow follicles but lower white follicles. Liver and pancreatic hypertrophy were observed for CBC-fed layers but with reduced $(P<0.05)$ abdominal fat and oviduct length. The long term feeding of CBC at levels more than $50 \mathrm{~g}$ $\mathrm{kg}^{-1}$ diet progressively had a deteriorating effect on laying performance and follicular development.
\end{abstract}

Key Words: Cocoa bean cake, inclusion rate, layers, egg quality, follicular measurements.

\section{INTRODUCTION}

Increasing cost of conventional feedstuffs has contributed immensely to the low level of animal protein intake in the diets of people of tropical Africa. This is more apparent because animals compete with man for similar foodstuffs. The situation is likely to worsen if unconventional sources of ingredients are not identified and evaluated at all stages of animal life.

Cocoa bean cake is a fat-extracted residue and by-product of industries processing low grade cocoa beans. It is an unconventional feed ingredient that could be utilized by poultry and is not consumable by man. It contains $23 \%$ crude protein, $16.5 \%$ ether extract, $5.75 \%$ crude fibre and $2.24 \%$ theobromine (Odunsi and Longe, 1995a). Previous reports (Odunsi and Longe, 1995a; Owusu-Domfeh et. al., 1970; Black and Barron, 1943) had indicated its toxity and suggested feeding at low levels or its detheobrominisation. Alternatively, it could be gradually introduced (Hutagalung and Chang, 1978) or fed to older animals (Braude, 1943). Odunsi and Longe (1995a,b) observed that pullet chicks can only tolerate up tc $200 \mathrm{~g}$ $\mathrm{kg}-1 \mathrm{CBC}$ at the starter and grower phases.

This trial, therefore, aimed at providing information on the productive performance, and some physiological responses of longterm feeding of cocoa bean cake to layers.

\section{MATERIALS AND METHODS}

The origin and collection of cocoa bean cake used has been described (Odunsi and Longe, 1995a). Sixty Isa brown pullets (20 weeks old) were randomly selected from groups of birds reared from day old on diets containing either $\mathrm{O}, 50,100$ or $200 \mathrm{~g} \mathrm{~kg}^{-1} \mathrm{CBC}$ at starter and grower phases. Fifteen pullets per dietary treatment were individually caged with each bird acting as a replicate. They were maintained on the same levels of $\mathrm{CBC}$. received during the rearing stage but now on a layers dietary regime (18\% $\mathrm{CP}$ and $10.9 \mathrm{MJ}$ $\mathrm{kg}^{-1} \mathrm{ME}$ ) as shown in Table 1 until 54 weeks of age, Feed and water were provided ad libitum. Sexual maturity and egg weights at maturity were noted. Body weight changes and egg quality indices were monitored at 2-week intervals while egg production and egg weights were determined weekly. Egg yolk and whole egg cholesterol were determined in triplicates per week by the procedure of Folch 
TALE 1: COMPOSITION OF DIETS COUNSI

BEAN CAKE FED TO CONTAMMNG GRADED LEVELS OF COCOA TO LAYEAS DUAHG 20 - 54 WEEKS

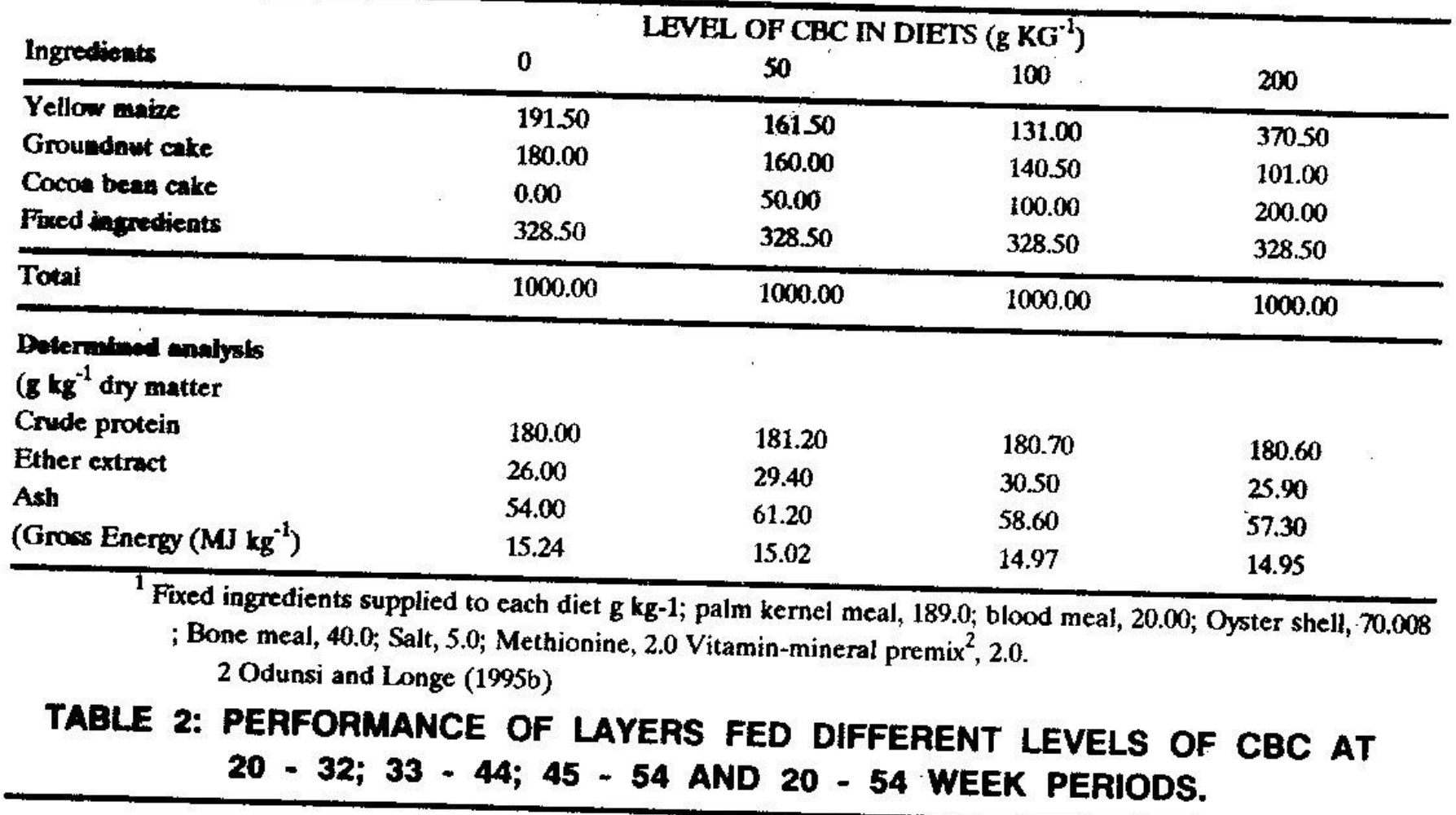

Parameters

Age at first egs (days)

Weight of first ezg (gm)

Hen day production \%

$$
\begin{aligned}
& 20-32 \text { weeks } \\
& 33-44 \text { weeks } \\
& 45-54 \text { weeks } \\
& 20-54 \text { wreks }
\end{aligned}
$$

Esg Weight (rm)

$$
\begin{aligned}
& 20-32 \text { weeks } \\
& 33-11 \text { weeks } \\
& 45-54 \text { weeks } \\
& 20-54 \text { weeks }
\end{aligned}
$$

Feed lable (om/bind/day)

$$
\begin{aligned}
& 20-32 \text { weeks } \\
& 33-44 \text { weeks } \\
& 45-54 \text { weeks } \\
& 20.54 \text { weeks }
\end{aligned}
$$

Body Weight gain (kg)

$$
\begin{aligned}
& 20-32 \text { weeks } \\
& 33-44 \text { weeks } \\
& 45-54 \text { weeks } \\
& 20-54 \text { weeks }
\end{aligned}
$$

Feed Efficiency

20 - 32 weeks

33 - 44 weeks
LEVEL OF CBC IN DIETS G KG ${ }^{-1}$

$\begin{array}{lllll}0 & 50 & 100 & 200 & \text { SEM }\end{array}$

$\begin{array}{llllll}157.00 & 174.00 & 186.00 & 191.00 & - \\ 44.50 & 46.50 & 54.24 & 49.10 & - \\ & & & & \\ 41.31^{\mathrm{a}} & 35.84^{\mathrm{a}} & 17.62^{\mathrm{b}} & 8.99^{\mathrm{b}} & 3.24 \\ 67.59^{\mathrm{a}} & 59.88^{\mathrm{a}} & 41.93^{\mathrm{b}} & 40.24 \mathrm{~b} & 3.17 \\ 64.64^{\mathrm{a}} & 65.86^{\mathrm{a}} & 46.25^{\mathrm{b}} & 33.33 \mathrm{~b} & 2.79 \\ 54.93^{\mathrm{a}} & 56.27^{\mathrm{a}} & 33.42^{\mathrm{b}} & 14.24 \mathrm{c} & 3.18\end{array}$

$\begin{array}{lllll}57.39^{\text {ab }} & 56.15^{\text {ab }} & 60.49 \mathrm{a} & 51.11^{\mathrm{b}} & 0.79 \\ 60.31^{\mathrm{a}} & 57.37^{\mathrm{ab}} & 58.55^{\mathrm{a}} & 54.23^{\mathrm{b}} & 0.62 \\ 60.70 & 58.95 & 60.00 & 57.40 & 0.58 \\ 59.27^{\mathrm{a}} & 57.65^{\mathrm{a}} & 59.87 \mathrm{a} & 54.12 \mathrm{~b} & 0.50\end{array}$

$94.86^{\text {ab }} \quad 96.70^{\mathrm{a}} \quad 91.08^{\mathrm{b}} \quad 82.83^{\mathrm{c}} \quad 1.17$

$\begin{array}{lllll}108.75^{\mathrm{a}} & 104.47^{\mathrm{ab}} & 87.66^{\mathrm{b}} & 78.40^{\mathrm{c}} & 2.32\end{array}$

$109.27^{\mathrm{a}} \quad 102.06^{\mathrm{b}} \quad 91.94^{\mathrm{c}} \quad 45.83^{\mathrm{c}} \quad 2.98$

$\begin{array}{lllll}102.27^{\mathrm{a}} & 101.01^{\mathrm{a}} \quad 90.11^{\mathrm{b}} \quad 82.08^{\mathrm{c}} \quad 1.58\end{array}$

$\begin{array}{lllll}0.31^{\mathrm{c}} & 0.42^{\mathrm{bc}} & 0.56^{\mathrm{ib}} & 0.62^{\mathrm{i}} & 0.03 \\ 0.18^{\mathrm{c}} & 0.14^{\mathrm{i}} & 0.01^{\mathrm{b}} & -0.015^{\mathrm{b}} & 0.02 \\ -0.0 .3 & -0.15^{\mathrm{b}} & 0.13 & -0.10 & 0.04 \\ 0.45^{\mathrm{ab}} & 0.39^{\mathrm{b}} & 0.60^{\mathrm{a}} & 0.47^{\mathrm{ab}} & 0.03\end{array}$

$\begin{array}{lllll}5.12^{\mathrm{b}} & 7.06^{\mathrm{b}} \quad 11.35^{\mathrm{b}} \quad 54.67^{\mathrm{a}} \quad 4.10\end{array}$

$2.68^{\mathrm{b}} \quad 2.7 .3^{\mathrm{b}}, \quad 3.84^{\mathrm{a}} \quad 4.00^{\mathrm{a}} \quad 0.10$ 


\begin{tabular}{llllll}
\hline & \multicolumn{5}{c}{ LEVEL OF CBC IN DIETS $\left(\mathrm{g} \mathrm{KG} \mathrm{i}^{-1}\right)$} \\
Parameters & 0 & 50 & 100 & $200^{\circ}$ & SEM \\
\hline Haugh unit (\%) & $73.79^{\mathrm{b}}$ & $73.95^{\mathrm{ab}}$ & $78.11^{\mathrm{ab}}$ & $80.49^{\mathrm{a}}$ & 0.93 \\
Shell thickness (mm) & $0.38^{\mathrm{a}}$ & $0.35^{\mathrm{b}}$ & $0.34^{\mathrm{b}}$ & $0.32^{\mathrm{c}}$ & 0.04 \\
Yolk colour (Roche Fan No) & $7.49^{\mathrm{b}}$ & $7.69^{\mathrm{c}}$ & $7.84^{\mathrm{b}}$ & $8.65^{\mathrm{a}}$ & 0.14 \\
Yolk index & 0.41 & 0.42 & 0.43 & 0.44 & 0.01 \\
Mean egg yolk cholesterol (mm/gm cgg) & 13.53 & 13.02 & 12.87 & n.a. & 0.38 \\
Whole egg cholesterol (mm/gm egg) & 3.72 & 3.81 & 3.64 & n.a.a & 0.07 \\
\hline
\end{tabular}

n.a - not available

Means without common superseripts in horizontal rows are signilieantly different $(\mathrm{P}<0.05)$.

et al (1956) as modified by Washburn and Nix (1974) during the last 4 wecks of study. At the 54th week of age, 5 birds per treatment were sacrificed except for the birds on $200 \mathrm{~g} \mathrm{~kg}^{-1}$ CBC diet for which mortality had reached $100 \%$. The liver, pancreas, oviduct and abdominal fat were carefully removed and weighed. Follicular number and type were counted with the aid of hand lens while diameter was measured using vernier caliper, and grouped into ranges hetween $0-3.0 \mathrm{~mm}$. Proximate analysis of the diets were carried out (AOAC, 1990) and gross energy values determined with a Parr adiabatic bomb calorimeter.

Results were evaluated by analysis of variance with signifcant differences between treatment means assessed by the Duncan's Multiple range test (Steel and Torrie, 1980). Data on some parameters were subjected to linear regression analysis (Gomez and Gomez. 1985).

\section{RESULTS AND DISCUSSION}

Performance data (Table 2) show a delay in sexual maturity (age at first egg) by about 17 , 29 and 34 days for pullets on 50,100 and $200 \mathrm{~g}$ $\mathrm{kg}^{-1} \mathrm{CBC}$ diets respectively. Hen day production (HDP) was bettcr $(\mathrm{P}<0.05)$ for 0 and $50 \mathrm{~g} \mathrm{~kg}^{-1} \mathrm{CBC}$ diets compared to 100 and $200 \mathrm{~g} \mathrm{~kg}^{-1} \mathrm{CBC}$ diets which were similar. Feed consumption declined $(\mathrm{P}<0.05)$ with inclusion of $\mathrm{CBC}$ even though layers on 0 and $50 \mathrm{~g} \mathrm{~kg}^{-1}$ $C B C$ diet had similar $(P>0.05)$ intake except during the 45-54 week period. During the rearing phase, decreases in feed and emergy intakes by pullets on C.BC based - diets were observed which could be likened to a feed restriction model (Iohnson et al. 1984) consequently resulting in lower body weights at 20 weeks and a delay in sexual maturity. Pullets on 0, 50, 100 and $200 \mathrm{~g} \mathrm{~kg}^{-1}$ CBC diets allaine' $50 \%$ HDP by $24,25,31$ and 34 weeks of age iespectively. The low egg production at levels more than $50 \mathrm{~g} \mathrm{~kg}^{-1}$ CBC seemed to be associated with reduced feed consumption duc to the theobromine content and changes in dietary profile. The low chemical score and essential amino acid index for cocoa products (Owusu - Domfeh, et al, 1970) may also be contributory factors to reduced performance. Theobromine is known to reduce intake duc to its bitter taste and becomes toxic when it accumulates in the body (Greenwood - Barton, 1965), as the rate of excretion is low. The higher weight gain for 100 and $200 \mathrm{~g} \mathrm{~kg}^{-1}$ CBC: fed-layers during 20-32 weck and 33-44 week periods was an indication that the nutrients consumed were principally used for maintenance and tissue lay-down (Degen et al. 1988) leaving little for egg production. This was further reflected on the poor feed efficiency ( $\mathrm{kg}$ feed $/ \mathrm{kg}$ egg) recorded during the 20-32 week period for $200 \mathrm{~g} \mathrm{~kg}^{-1}$ CBC diet. Feed efficiency allowed CBC to be included up to $100 \mathrm{~g} \mathrm{~kg}^{-1}$ level.

Egg quality data (Table 3) show an increase in the Haugh unit and yolk colour while shell thickness decreased with increasing levels of CBC. Cocoa contains traces of oxalic acid (Harland, 1989) which combine easily with calcium to form calcium oxalate, heand, the 
TABLE 4: EFFECT OF DIETARY LEVELS OF CBC ON FOLLICULAR

PARAMETERS, ABDOMINAL FAT, OVIDUCT LENGTH AND ORGAN WEIGHTS (AS A PERCENT OF LIVEWEIGHT).

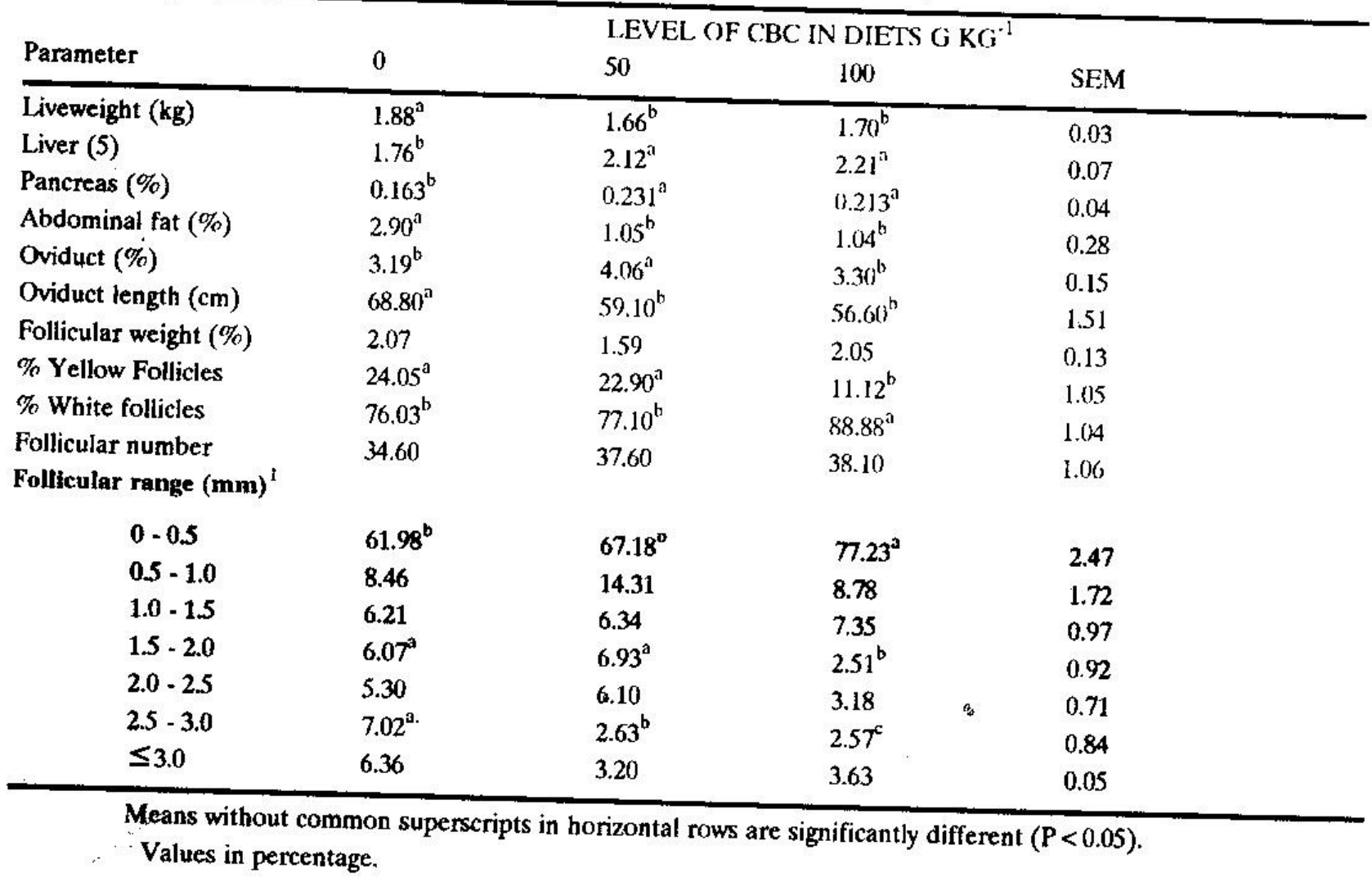

may reduce availability of calcium for egg formation resulting in thin shells. There is dearth of information on the effect of CBC based-diets on egg cholesterol which was found to decrease $(P>0.05)$ with increase in CBC. It appears that mechanisms of absorption, synthesis, catabolism and excretion of cholesterol by layers (Attia et al, 1988) in the eggs may have been ably maintained thus accounting for the little variations ovserved.

Data on liveweight and organ weights are shown in Table 1. Liver and pancreatic hypertrophy implicated theobromine (Odunsi and Longe, 1995a). Symptoms associated with theobromine poisoning had been described (Odunsi and Longe, 1995a; Woodman, 1911). The liver of affected birds, apart from being enlarged, had a deep mahogany colour while the kidneys were mottled. The low abdominal fat deposit on CBC fed layers may be due to caloric intake and addional call on body reserves for egg production. Follicular number and weight were not affected $(P>0.05)$ by dietary treatments while follicular type revealed reductions $(\mathrm{P}<0.05)$ at the $100 \mathrm{~g}$ $\mathrm{kg}^{-1} \mathrm{CBC}$ diet for yellow follicles and increase for white follicles. Egg production exhibited a direct relationship with follicular size and type. Layers fed $100 \mathrm{~g} \mathrm{~kg}^{-1} \mathrm{CBC}$ diet had more white follicles in the lower size range hence fewer numbers attained the size necessary for further egg development (Hookings et al, 1989) compared to layers on 0 and $50 \mathrm{~g} \mathrm{~kg}^{-1}$ $\mathrm{CBC}$ diets which had more yellow follicles and produced more eggs. It is possible that $\mathrm{CBC}$ exhibited its effect on follicular development by decreasing the rate at which yellow follicles are formed or by increasing the rate of atresia of the white follicles. Table 5 shows the regression equations between levels of $\mathrm{CBC}$ and some parameters. There were positive correlations $(r-0.96,0.93,0.95,0.71)$ with age at first egg, feed efficiency, Haugh unit and liver weight respectively but negative correlations for HDP, DFI, shell thickness and abdominal fat respectively. (Table 5)

Inclusion of CBC up to $200 \mathrm{~g} \mathrm{~kg}^{-1}$ level caused heavy mortality and a reduced performance while birds on $50 \mathrm{~g} \mathrm{~kg}^{-1} \mathrm{CBC}$ diet performed equally as good as those on the 


\begin{tabular}{|c|c|c|c|c|}
\hline \multirow[b]{2}{*}{ Dependent variable } & \multicolumn{4}{|c|}{ LEVEL OF CBC IN LAYER DIET AS INDEPENDENT VARIABLE ( } \\
\hline & Regression equation & $\mathbf{R}$ & SER & Significance \\
\hline Age at first egg (day) & $Y=162.8+1.62 X$ & 0.92 & 5.71 & ns \\
\hline Weight of first egg (gm) & $Y=46.33+0.26 X$ & 0.52 & 3.41 & ns \\
\hline Hen-day production (\%) & $Y=56.48-2.25 X$ & -0.96 & 6.62 & $\mathbf{x}$ \\
\hline Daily feed intake $(\mathrm{gm})$ & $Y=103.73 \cdot 1.11 X$ & -0.97 & 2.15 & $\mathbf{x}$ \\
\hline $\mathrm{kg} \mathrm{feed} / \mathrm{kg} \mathrm{eggs}$ & $Y=1.66+0.50 X$ & 0.93 & 1.56 & ns \\
\hline Haugh unit $(\%)$ & $Y=73.10+0.36 X$ & 0.95 & 0.03 & $\mathbf{x}$ \\
\hline Shell thickness (cm) & $Y=0.37-0.003$ & 0.75 & 0,004 & $\mathbf{x}$ \\
\hline Yolk colour (Fan No) & $Y=7.41+0.06 X$ & 0.40 & 0.20 & $\mathbf{x}$ \\
\hline Liveweight (kg) & $Y=1.83-0.02$ & -0.62 & 0.04 & $x^{-}$ \\
\hline Liver (\%) & $Y=1.80+0.05 X$ & 0.71 & 0.08 & $x$ \\
\hline Pancreas (\%) & $Y=0.18+0.005 X$ & 0.49 & 0.02 & ns \\
\hline Abdominal fat (\%) & $Y=2.59-0.19 x$ & -0.73 & 0.32 & ns \\
\hline $\begin{array}{l}\text { EE yolk cholesterol } \\
\text { (mg/gm egg). }\end{array}$ & $Y=13.47-0.07 X$ & -0.95 & 0.64 & $\mathbf{x}$ \\
\hline
\end{tabular}

$$
\mathrm{X}=\mathbf{P}<0.05
$$

$\mathrm{ns}=$ not significant

control diet. Observations revealed that $46.6 \%$ of the birds on $200 \mathrm{~g} \mathrm{~kg}^{-1} \mathrm{CBC}$ diet died within 20-32 week, 40\% during 33-44 week and the rest $\mathrm{a} / \mathbf{4 5 - 5 4}$ week periods. Layers on $50 \mathrm{~g} \mathrm{kg-1}$ CBC diet had no mortality while $20 \%$ and $6.7 \%$ were recorded for 100 and $0 \mathrm{~g} \mathrm{~kg}-1 \mathrm{CBC}$ diets respectively. This study showed that follicular development was impeded by the presence of theobromine in CBC based-diets which ultimately affected egg production. Further studies that would aim at reducing the level of theobromine in CBC or neutralise it completely are advocated.

\section{ACKNOWLEDGEMENT}

The author thanks Mr Sunny Ituen for his assistance during the feeding trial.

\section{REFERRENCES}

AOAC, (1990). Association of official Analytical Chemists. Official Methods of Analysis 15th edn, Washington, D.C.

ATTIA, F.M. ALSOBAYEL, A.A., SHAVER M.E., BAYOUMI, M.S. and HASSAN, H.A. (1988). Comparative aspects of serum and egg cholesterol of single comb white leghorn and Saudi Arabian Baladi fowl. Arab Gulf J.sci. Res. Agric. Bio. Sci. B6(3): 129-137.
BLACK, J.G. anD BARRON, N.S. (1943) Observations on the feeding of cocoa waste to poultry. Vet Bat Rec. 55: 166-167.

BRAUDE, R. (21943). Toxic effects in the feeding of cocoa meal to pigs. Vet J99: 302-307

DEGEN, A.A.; KAM. N. AND RESENTBRAUCH, S. (1988). Efficiency of utilization of energy for egg production in feed restricted single comb while leghorn hens. J. Agric. Sci. Camb. 3: 303 - 308.

FOLCH, J.; LEES, M. AND SLOANE-STANLEY,G.H.(1956). A simple method for the isolation and purification of total lipids from animal tissues. $J$. of biol Chem. 326: 147 - 506.

GOMEZ, A.K. and GOMEZ, A.A. (1985). Statistical procedures for agricultural research, Wiley, New York.

GREENWOOD-BARTON, L.H. (1985). Utilization of cocoa by-products. Feed Manuf. 10(5): 52-56

HARLAND, B. F. (1989). Dietary fiber and mineral bioavailability Nutr. Res. Rev. 2:133 147.

HOCKINGS, P.M.; WADDINGTON, D.; WALTER, M.A.; GILBERT, A.R. (1988). 


\section{ODUNSI}

Control of the development of the ovarian follicular hierarchy in broiler breeder pullets by food restriction during rearing. Brit. Poult. Sci. 30: 161 - 174.

HUTAGALUNG, R.I. and CHANG, C.C. (1978). Utilization of cocoa by-products as animal feed. Int. Conf. on cocoa and coconut. June $21-24,1978$. Malaysia ed. Devendral C. and Hutagalung, R.I. Reprint No. 25, 9 pp.

JOHNSON, R.J.; AMANDA, C.; FARRELL, D.J. and CUMMING R.B. (1984). Production responses of layer strain hens to food restrictions during rearing. Brit Poult. Sci. 25: 369 - 387.

ODUNSI, A.A. and LONGE O.G. (1995a). Cocoa bean cake in poultry diets (1): Chemical composition and nutritive value of cocoa bean cake in pullet chick diets.J. Appl. Anim. Res. 7:91 - 98.
ODUNSI, A.A. and LONGE O.G. (1995b). Cocoa bean cake in poultry diets (2): Effects of feeding cocoa bean cake on growth and laying performance of pullets. J. Appl. Anim. Res. 7:137 - 144

OWUSU-DOMFEH, K. CHRISTENSEN, D.A. and OWEN, B.D. (1970). Nutritive value of some Ghananian feedstuffs. Can J. Anim. Sci. 50: 1-14

STEEL, R.G.D. and TORRIE, J.H. (1980). Principles of Statistics 2nd Edn. McGraw-Hill Book Co., New York.

WASHBURN, K.W. and NIX, D.F. (1974). A rapid technique for extraction of yolk cholesterol. Poult Sci. 53: 1118 - 1122.

WOODMAN, H.E. (1941). Poisoning by Cocoa Shell. J. Min. Agric. England 48: 45-46 